\title{
PENGARUH DUKUNGAN KELUARGA, KUALITAS PEMBELAJARAN DAN MOTIVASI BELAJAR TERHADAP PRESTASI BELAJAR AGAMA HINDU ANAK RETARDASI MENTAL DI SLB D YPAC BALI
}

\author{
Oleh \\ Ayu Putu Dewi Ary Sukanti \\ SLB N 1 Badung \\ ayou_theywee@yahoo.com
}

\begin{abstract}
Family support on learning achievement of Hinduism through the regression line equation $=50.393+0.376$ X1 with a contribution of $50.8 \%$ and an effective contribution of $19.0 \%$, (2) there is an effect of learning quality on learning achievement of Hinduism through the regression line equation: $=55.578+0.314 \times 2$ with a contribution of $52.2 \%$ and a contribution of $19.3 \%$, (3) there is an influence of learning motivation on the learning achievement of Hindu teachers through regression line equations $=55.549+0.318 \mathrm{X3}$ with a contribution of $71.9 \%$ and effective contribution of $41.7 \%$, and (4) there is a joint influence between family support, learning quality, and learning motivation on learning achievement of Hindu teachers through regression line equations $=45.676+0.141 \mathrm{X} 1+0.116 \mathrm{X2}+0.185$ $X 3$ contribution with amounted to $41.7 \%$. Based on these findings, it can be ignored that there is a positive and significant influence between family support, learning quality, and learning motivation on learning achievement of Hinduism for children with mental retardation in SLB D YPAC Bali separately or simultaneously.
\end{abstract}

Keywords: Family Support, Learning Quality, Learning Motivation, Hindu Learning Achievement

\section{PENDAHULUAN}

Pendidikan agama dalam pendidikan luar biasa merupakan salah satu pendidikan yang terpenting dalam membantu perkembangan jiwa anak khususnya membantu dalam perkembangan etika dan moral, untuk itu pendidikan agama di Indonesia mendapatkan prioritas yang utama dalam sistem pendidikan, yang dimasukkan ke dalam kurikulum atau silabus mulai dari pendidikan dasar, menengah sampai dengan pendidikan tinggi tidak terkeculai pada Pendidikan Khusus dengan harapan nantinya, melalui pendidikan agama yang dimiliki anak dengan kekhususan tertentu dapat memiliki ahlak, etika dan moral yang baik.

Pendidikan khusus adalah pendidikan bagi anak yang mengalami hambatan dalam proses pembelajaran. Banyak anak berkebutuhan khusus yang dilayani dalam Pendidikan Khusus atau yang biasa dikenal sekolah luar biasa, salah satunya yaitu anak Retardasi Mental (RM). RM adalah suatu keadaaan seseorang yang mengalami hambatan intelektual dengan kemampuan dibawah rata- rata. Hal ini adalah salah satu faktor yang menyebabkan banyaknya kendala yang timbul dalam proses pembelajaran dari anak RM. Faktor - faktor

Pengaruh Dukungan Keluarga, Kualitas Pembelajaran dan Motivasi Belajar terhadap Prestasi Belajar Agama Hindu Anak Retardasi Mental Di SLB D YPAC Bali 
tersebut muncul dari dalam diri anak (internal) dan juga dari luar diri anak (eksternal) yang akan mempengaruhi hasil belajar atau prestasi belajar anak RM.

Faktor internal yang berasal dari dalam diri anak RM adalah motivasi belajar. Motivasi belajar merupakan sebuah dorongan semangat bagi anak untuk melakukan aktivitas belajar. Anak akan termotivasi untuk mengikuti pembalajaran, jika suasana belajar yang diikuti menyenangkan, anak tidak akan merasa terbebani mengikuti proses karena tujuan dari belajar adalah untuk mendapatkan pengalaman baru dalam situasi yang nyaman. Selain faktor internal keberhasilan anak dalam pembelajaran juga sangat dipengaruhi oleh faktor eksternal, dalam hal ini dengan melihat keadaan anak $\mathrm{RM}$ tentu yang sangat berpengaruh adalah dukungan keluarga.

Dukungan keluarga adalah tindakan positif keluarga sebagai lingkungan yang mengetahui latar belakang, kebiasaan bahkan mungkin mengetahui minat, bakat, kelebihan kekurangan dan kebiasaan anak mengingat waktu anak lebih banyak berada dalam lingkungan keluarga. Selain dukungan keluarga, ada juga faktor eksternal lain yang mempengaruhi keberhasilan anak dalam hasil belajar atau prestasi belajar yang diharapkan, salah satu adalah rendahnya kualitas pembelajaran. Banyak hal yang mempengaruhi rendahnya mutu pendidikan atau kualitas pembelajaran seperti: pengelolaan kelas, sarana prasarana dan efisensi waktu. Dalam proses pembelajaran, khususnya bagi anak berkebutuhan khusus dalam hal ini adalah anak Retardasi Mental (RM) guru mempunyai peranan yang sangat penting. Dalam Pendidikan Khusus Tugas guru tidak hanya mendidik, mengajar dan menyampaikan ilmu yang sesuai dengan bidang kompetensinya tetapi juga sebagai fasilitator yang tahu akan kebutuhan anak melalui hasil asesmen mengingat setiap anak berkebutuhan khusus memiliki minat, bakat dan karakteristik yang berbeda - beda meski berada dalam kelas yang sama karena memiliki usia mental yang beragam. Setiap anak RM memiliki keunikannya masingmasing.

Prestasi Belajar yang diketahui melalui hasil belajar Pendidikan Agama Hindu bagi anak RM juga penting, karena dengan mendapatkan pendidikan agama diharapkan anak RM dapat meningkatkan moral dan etika. Anak RM memerlukan pendidikan Agama yang disesuaikan dengan taraf IQ-nya, mereka digolongkan yang mampu didik atau golongan RM ringan, dan yang mampu latih untuk anak RM. Untuk melihat prestasi belajar anak RM, peneliti melihat dari nilai raport masing-masing anak.

Berdasarkan hasil observasi yang dilakukan, banyak anak yang tidak bersemangat mengikuti pembelajaran agama Hindu dengan alasan, mengantuk, bosan dan banyak alasan anak agar tidak mengikuti pembelajaran tersebut. Bahkan tidak jarang ada beberapa anak RM yang keluar kelas saat pelajaran berlangsung, peneliti juga mendapatkan 7 anak RM dari 12 orang anak RM dalam satu kelas yang mendapatkan nilai kurang dari KKM sebagai standar yang telah ditetapkan oleh SLB D YPAC Bali, selain itu dari hasil wawancara masih banyak anak RM yang tinggal diluar asrama tidak pernah melakukan aktivitas sembahyang secara rutin, berbeda dengan pola aktivitas yang dilakukan oleh anak RM yang tinggal diasrama karena pengasuh membuatkan jadwal aktivitas harian.

Pada tulisan ini penulis berusaha untuk menjelaskan Pengaruh Dukungan Keluarga, Kualitas Pembelajaran dan Motivasi Belajar Terhadap Prestasi Belajar Agama Hindu Anak Retardasi Mental (RM) di SLB D YPAC Bali. 


\section{METODE}

\section{a. Rancangan Penelitian}

Jenis penelitian ini adalah penelitian noneksperimen. Desain penelitian ini adalah penelitian yang berupaya mengetahui pengaruh antara variabel bebas (prediktor) dan variabel terikat (kriterium) tanpa memanipulasi suatu data.. Dalam penelitian ini akan dicari untuk kontribusi antar variabel, yaitu variabel Dukungan keluarga $\left(\mathrm{X}_{1}\right)$ terhadap Prestasi belajar $(\mathrm{Y})$, variabel Kualitas Pembelajaran $\left(\mathrm{X}_{2}\right)$ terhadap Prestasi belajar (Y),variabel Motivasi belajar $\left(\mathrm{X}_{3}\right)$ terhadap Prestasi belajar (Y) serta variabel Dukungan keluarga $\left(\mathrm{X}_{1}\right)$, Kualitas Pembelajaran $\left(\mathrm{X}_{2}\right)$ dan Motivasi belajar $\left(\mathrm{X}_{2}\right)$ Prestasi belajar (Y).

\section{b. Variabel Penelitian dan Definisi Operasional}

1. Dalam penelitian ini terdiri atas variabel bebas/prediktor yaitu dukungan keluarga, kualitas pembelajaran dan motivasi belajar sedangkan variabel terikat/kriterium adalah prestasi belajar agama Hindu anak retardasi Mental.

2. Definisi operasional yaitu terdiri dari pengertian dukungan keluarga adalah dorongan sosial positif yang didapatkan dari lingkungan terdekat, kualitas pembelajaran adalah tingkat capaian tujuan pembelajaran dan motivasi belajar adalah dorongan semangat untuk melakukan aktivitas belajar sedangkan prestasi belajar adalah proses perubahan tingkah laku dari hasil belajar yang dapat dinilai secara teori dan praktik.

\section{c. Populasi dan Sampel Penelitian}

Populasi dalam penelitian ini adalah seluruh anak RM ringan di SLB D YPAC Bali, dalam penelitian ini sampel yang digunakan adalah anak RM ringan dengan jumlah anak RM sebanyak 30 orang.

\section{d. Instrumen Penelitian}

1. Penyusunan Instrumen, instrumen yang disusun terdiri atas tiga yaitu instrumen dukungan keluarga, instrumen kualitas pembelajaran dan instrumen motivasi belajar sedangkan prestasi belajar anak RM dapat diperoleh dengan menggunakan metode pencatatan dokumen. Pencatatan dokumen yang dimaksud adalah dengan melihat hasil belajar anak berupa nilai yang tertera pada buku raport dan hasil ujian akhir semester (UAS).

2. Uji Coba Instrumen, Sebelum instrumen digunakan, diuji coba terlebih dahulu. Uji coba dilakukan untuk memeriksa kesahihan baik isi maupun validitas konstruk serta kehandalan sehingga angket tersebut memenuhi syarat untuk digunakan. Setelah melakukan uji coba, selanjutnya dilakukan analisis item untuk memeriksa validitas dan reliabilitas dari masing-masing item.

3. Hasil Uji Coba Instrumen, Instrumen penelitian diujicobakan terhadap 30 responden yang ada di luar sampel penelitian, semua instrumen memiliki reliabilitas yang sangat tinggi. Ada 20 butir kuesioner dukungan orang tua yang terpakai. Kuesioner kualitas pembelajaran, dari 20 semua butir dianggap valid. Kuesioner motivasi belajar dari 20 butir, semuanya dinyatakan valid.

4. Prosedur Penelitian yaitu Masing masing orang tua, guru dan anak RM diberikan angket, Pengisian angket diberikan secara langsung oleh peneliti kepada response, hal ini dilakukan agar terjadi komunikasi antara peneliti dan responden, Pengisian angket dilakukan pada orantua anak RM, dan khusus untuk anak RM pengisian angket diadakan pendampingan oleh guru dan orangtua. Pengumpulan angket dilakukan sendiri oleh peneliti, Setelah data terkumpul, 
selanjutnya dilakukan uji prasyarat analisis untuk menjamin reliabilitas dan validitas data yang diperoleh.

5. Teknik Analisa Data Teknik analisis data diarahkan pada pengujian hipotesis yang diajukan serta untuk menjawab rumusan masalah. Dalam penelitian ini terdapat tiga uji hipotesis, sebagai berikut:1) Pengaruh dukungan keluarga terhadap prestasi belajar agama Hindu anak RM di SLB D YPAC Bali, 2) Pengaruh Kualitas Pembelajaran terhadap prestasi belajar agama Hindu anak RM di SLB D YPAC Bali, 3) Pengaruh motivasi belajar terhadap prestasi belajar agama Hindu anak RM di SLB D YPAC Bali, 4) Pengaruh dukungan keluarga, kualitas pembelajaran dan motivasi belajar terhadap prestasi belajar agama Hindu anak RM di SLB D YPAC Bali. Peneliti menggunakan analisis statistik inferensial regresi 2 prediktor untuk menelaah pengaruh dua variabel atau lebih, menguji pertautan 2 buah prediktor $\left(\mathrm{X}_{1}\right.$ dan $\left.\mathrm{X}_{2}\right)$ dengan variabel kriterium (Y) dalam suatu fenomena.

\section{PEMBAHASAN}

Disajikan hasil penelitian yang mencakup deskripsi tentang karakteristik masin-masing variabel penelitian, uraian tentang hasil pengujian persyaratan analisis dan uji hipotesis. Hasil penelitian yang dimaksudkan adalah menyangkut pengaruh dukungan keluarga, kualitas pembelajaran dan motivasi belajar terhadap prestasi belajar Agama Hindu pada Anak RM SLB D YPAC Bali. Dalam laporan hasil penelitian ini disajikan hal - hal sebagai berikut : (1) deskripsi data hasil penelitian. Statistik Deskriptif Variabel Hubungan Dukungan keluarga, Kualitas pembelajaran dan Motivasi belajar Terhadap
Prestasi belajar Agama Hindu menunjukkan bahwa rata-rata variabel dukungan keluarga Hindu adalah 78,876 skor minimum yang dicapai adalah 65 sedangkan skor maksimumnya adalah 88. Kualitas pembelajaran nilai rata-rata variabelnya adalah : 78,100 skor minimumnya 58, dan skor maksimumnya 89 . Nilai rata-rata variabel motivasi belajar 77,000 skor minimum 57 dan skor maksimumnya adalah 91. prestasi belajar Agama Hindu nilai ratarata variabelnya adalah 80,087 Skor minimumnya 75 dan skor maksimumnya 86 . Secara umum rata-rata skor dukungan keluarga Anak RM SLB D YPAC Bali diperoleh sebesar 78,876 dengan simpangan baku (standar deviasi) sebesar 6,367. Skor kualitas pembelajaran anak SLB D YPAC Bali diperoleh sebesar 78,100 dan simpangan baku (standar deviasi) sebesar 7,748. Skor motivasi belajar di Anak SLB D YPAC Bali diperoleh sebesar 77,000 dan simpangan baku (standar deviasi) sebesar 8,952 dan skor prestasi belajar Agama Hindu adalah 80,087 dan standar deviasi sebesar 3,362. (2) Uji persyaratan analisis terdiri atas pengujian normalitas sebaran data menggunakan uji Kolmogorov-Smirnov dan hasil terlihat bahwa untuk semua variabel, $p>0,05$. Ini berarti skor dukungan keluarga, skor kualitas pembelajaran, skor motivasi belajar, dan skor prestasi belajar Agama Hindu berdistribusi normal. Selanjutnya Uji linieritas garis regresi dimaksudkan untuk mengetahui keberartian koefisien arah regresi dari model linier antara variabel bebas dengan variabel terikat menggunakan uji $\mathrm{F}$ program SPSS menunjukkan bahwa untuk semua hubungan variabel, harga $\mathrm{F}$ linierity $\mathrm{F}$ hitung dengan

Pengaruh Dukungan Keluarga, Kualitas Pembelajaran dan Motivasi Belajar terhadap Prestasi Belajar Agama Hindu Anak Retardasi Mental Di SLB D YPAC Bali SLB N 1 Badung 
$\mathrm{p}<0,05$ dan untuk $\mathrm{F}$ Dev. from linierity $\mathrm{F}$ hitung dengan $\mathrm{p}>0,05$. Dengan demikian dapat disimpulkan bahwa hubungan antara dukungan keluarga, kualitas pembelajaran, dan motivasi belajar dengan prestasi belajar Agama Hindu mempunyai hubungan yang linier, kemudian hasil uji multikolinieritas terlihat bahwa $r_{x x}$ antar sesama variabel bebas kurang dari $0,800\left(\mathrm{r}_{\mathrm{xx}}<0,800\right)$, ini berarti antar sesama variabel bebas tidak terjadi multikolinieritas (nonkolinie), sedangkan hasil uji heteroskedastisitas adalah hubungan $\mathrm{Y}$ atas $\mathrm{X}_{1}, \mathrm{X}_{2}, \mathrm{X}_{3}$ tidak ada pola yang jelas, serta titik-titik menyebar di atas dan di bawah angka 0 pada sumbu $Y$, maka tidak terjadi heteroskedastisitas. Jadi dapat disimpulkan bahwa kelompok data variabel terikat (prestasi belajar Agama Hindu) atas slop regresi variabel bebas (skor dukungan keluarga, skor kualitas pembelajaran, dan skor motivasi belajar bersifat homogeny. Dan untuk mendeteksi autokurelasi umumnya dilakukan dengan uji statistik Durbin-Watson dengan hasil dalam regresi antara variabel bebas dukungan keluarga $\left(\mathrm{X}_{1}\right)$, kualitas pembelajaran $\left(\mathrm{X}_{2}\right)$, dan motivasi belajar $\left(\mathrm{X}_{3}\right)$ terhadap prestasi belajar Agama Hindu tidak terjadi autokorelasi. (3) pengujian hipotesis dengan hasil sebagai berikut:

Pengaruh Dukungan Keluarga Terhadap Prestasi Belajar Agama Hindu Anak RM di SLB D YPAC Bali

Terdapat hubungan yang positif dan signifikan antara dukungan keluarga terhadap prestasi belajar Agama Hindu melalui persamaan garis regresi $=50,393+0,376 \times 1$ dengan Freg $=28,856(\mathrm{p}<0,05)$. Dalam penelitian ini ditemukan korelasi positif yang signifikan antara dukungan keluarga dengan prestasi belajar Agama Hindu sebesar 0,712 dengan $p<0,05$. Hal ini berarti makin baik dukungan keluarga, makin baik prestasi belajar Agama Hindu.

Pengaruh Kualitas Pembelajaran Terhadap Prestasi Belajar Agama Hindu Anak RM di SLB D YPAC Bali

Terdapat hubungan yang positif dan signifikan antara kualitas pembelajaran terhadap prestasi belajar Agama Hindu melalui persamaan garis regresi: $=55,578+$ 0,314 X2 dengan Freg $=30,574(p<0,05)$. Dalam penelitian ini ditemukan korelasi positif yang signifikan antara kualitas pembelajaran dengan prestasi belajar Agama Hindu sebesar 0,722 $(\mathrm{p}<0,05)$ dengan kontribusi sebesar 52,2 \% Ini berarti, makin baik kualitas pembelajaran, maka makin baik pula prestasi belajar Agama Hindu.

Pengaruh Motivasi Belajar Terhadap Prestasi Belajar Agama Hindu Anak RM di SLB D YPAC Bali

Terdapat hubungan yang positif dan signifikan antara motivasi belajar terhadap prestasi belajar Agama Hindu guru melalui persamaan garis regresi $=55,549+0,318 \times 3$ dengan Freg $=71,528 \quad(p<0,05)$. Dalam penelitian ini ditemukan korelasi positif yang signifikan antara motivasi belajar dengan prestasi belajar Agama Hindu sebesar 0,848 $(\mathrm{p}<0,05)$ dengan kontribusi sebesar 71,9\%. Hal ini berarti makin tinggi motivasi belajar, maka makin tinggi pula prestasi belajar Agama Hindu.

Pengaruh Bersama-Sama antara Dukungan keluarga, Kualitas pembelajaran, dan Motivasi belajar Terhadap Prestasi belajar Agama Hindu Anak RM di SLB D YPAC Bali

Terdapat hubungan yang positif dan signifikan secara bersama-sama antara dukungan keluarga, kualitas pembelajaran, dan motivasi belajar terhadap prestasi belajar Agama Hindu guru melalui persamaan garis 
regresi $=45,676+0,141 \mathrm{X} 1+0,116 \mathrm{X} 2+$ 0,185 X3 dengan Freg $=34,706(p<0,05)$. Ini berarti secara bersama-sama variabel dukungan keluarga, kualitas pembelajaran, dan motivasi belajar dapat menjelaskan tingkat kecenderungan prestasi belajar Agama Hindu di Anak SLB D YPAC Bali. Dengan kata lain bahwa dukungan keluarga, kualitas pembelajaran, dan motivasi belajar berhubungan dengan prestasi belajar Agama Hindu Anak RM di SLB D YPAC Bali. Dari hasil analisis juga diperoleh koefisien korelasi ganda sebesar 0,895 dengan $\mathrm{p}<0,05$. Ini berarti, secara bersama-sama dukungan keluarga, kualitas pembelajaran, dan motivasi belajar berhubungan positif dengan prestasi belajar Agama Hindu Anak RM di SLB D YPAC Bali sebesar 41,7 \% artinya sekitar 41,7 \% variasi dalam variabel prestasi belajar Agama Hindu dapat dijelaskan oleh variabel dukungan keluarga, kualitas pembelajaran, dan motivasi belajar sedangkan sisanya ditentukan oleh variabel lain yang tidak diteliti. Makin tinggi dukungan keluarga, makin baik kualitas pembelajaran, dan makin tinggi motivasi belajar, makin tinggi pula prestasi belajar Agama Hindu.

dan (4) pembahasan hasil penelitian yaitu Variabel dukungan keluarga dapat menjelaskan makin tingginya prestasi belajar Agama Hindu sebesar 50,8 \%. Ini dapat dijadikan suatu indikasi bahwa dukungan keluarga dapat dipakai sebagai prediktor prestasi belajar Agama Hindu Anak RM di SLB D YPAC Bali atau dengan kata lain bahwa dukungan keluarga berhubungan terhadap prestasi belajar Agama Hindu Anak RM di SLB D YPAC Bali. Sumbangan efektif (SE) variabel dukungan keluarga terhadap prestasi belajar Agama Hindu sebesar $19,0 \%$. artinya sekitar $19,0 \%$ variasi dalam variabel prestasi belajar Agama Hindu dapat dijelaskan oleh variabel dukungan keluarga, sedangkan variabel kualitas pembelajaran dapat menjelaskan makin tingginya prestasi belajar Agama Hindu sebesar $52,2 \%$, ini dapat dijadikan suatu indikasi bahwa kualitas pembelajaran berhubungan terhadap prestasi belajar Agama Hindu Anak RM di SLB D YPAC Bali. Sumbangan efektif (SE) variabel kualitas pembelajaran terhadap prestasi belajar Agama Hindu sebesar 19,3\%. artinya sekitar 19,3\% variasi dalam variabel prestasi belajar Agama Hindu dapat dijelaskan oleh variabel kualitas pembelajaran, selanjutnya variabel motivasi belajar dapat menjelaskan makin tingginya prestasi belajar Agama Hindu sebesar 71,9\%, ini dapat dijadikan sebagai indikasi bahwa motivasi belajar berhubungan dengan prestasi belajar Agama Hindu Anak RM di SLB D YPAC Bali. Sumbangan efektif (SE) variabel motivasi belajar terhadap prestasi belajar Agama Hindu sebesar 41,7 \%. Artinya sekitar $41,7 \%$ variasi dalam variabel prestasi belajar Agama Hindu dapat dijelaskan oleh variabel motivasi belajar.Dari uraian di atas dapat dikatakan bahwa ketiga faktor tersebut sangat mempengaruhi prestasi belajar Agama Hindu pada anak . makin baik dukungan keluarga, kualitas pembelajaran, dan motivasi belajar suatu sekolah, maka makin baik pula prestasi belajar Agama Hindu di sekolah tersebut.

\section{Simpulan}

Berdasarkan analisis dan pembahasan dapat ditemukan hal-hal sebagai berikut: terdapat pengaruh dukungan keluarga terhadap prestasi belajar Agama Hindu melalui persamaan garis regresi $\hat{\mathrm{Y}}=50,393+0,376$ $\mathrm{X}_{1}$ dengan kontribusi sebesar 50,8 \% dan sumbangan efektif sebesar 19,0\%, Terdapat pengaruh kualitas pembelajaran terhadap prestasi belajar Agama Hindu melalui persamaan garis regresi: $\hat{\mathrm{Y}}=55,578+0,314$ $\mathrm{X}_{2}$ dengan kontribusi sebesar $52,2 \%$ dan

Pengaruh Dukungan Keluarga, Kualitas Pembelajaran dan Motivasi Belajar terhadap Prestasi Belajar Agama Hindu Anak Retardasi Mental Di SLB D YPAC Bali SLB N 1 Badung 
sumbangan efektif sebesar 19,3\%, Terdapat pengaruh motivasi belajar terhadap prestasi belajar Agama Hindu guru melalui persamaan garis regresi $\hat{\mathrm{Y}}=55,549+0,318$ $\mathrm{X}_{3}$ dengan kontribusi sebesar $71,9 \%$ dan sumbangan efektif sebesar $41,7 \%$ dan Terdapat pengaruh secara bersama-sama antara dukungan keluarga, kualitas pembelajaran, dan motivasi belajar terhadap prestasi belajar Agama Hindu guru melalui persamaan garis regresi $\hat{\mathrm{Y}}=45,676+0,141$ $\mathrm{X}_{1}+0,116 \mathrm{X}_{2}+0,185 \mathrm{X}_{3}$ dengan kontribusi sebesar $41,7 \%$.

Berdasarkan hasil temuan tersebut dapat disimpulkan bahwa terdapat pengaruh antara dukungan keluarga, kualitas pembelajaran, dan motivasi belajar terhadap prestasi belajar Agama Hindu Anak RM di SLB D YPAC Bali secara terpisah maupun simultan. Dengan demikian ketiga faktor tersebut dapat dijadikan prediktor tingkat kecenderungan prestasi belajar Agama Hindu Anak RM di SLB D YPAC Bali.

\section{DAFTAR PUSTAKA}

Delphie, Bandi. (2008). Pembelajaran Anak Berkebutuhan Khusus. Bandung: Refika Aditama.

Handayani, Dwi. (2008). Peranan Keluarga Terhadap Kecenderungan Sosiopatik dan Prestasi Belajar Pada Remaja SLTP. Singaraja: Undiksa.

Huda, Ahmadi Nur. Noerhidajati, Elly., Hastuti, Rizki Woro,. Maesaroh, Siti. (2020). Dukungan Psikososial terhadap Anak Penderita Retardasi Mental di SLB Widya Bhakti Semarang. Indonesian Journa Of Community Service. Vol 2 No 2. e-ISSN 26848619.

Hurlock, B. (2000). Psikologi Perkembangan. Suatu Pendekatan
Sepanjang Rentang kehidupan. Edisi 5. Jakarta: Erlangga.

Koyan,Wayan. (2012). Statistik Pendidikan Teknik Analisis Data Kuantitatif. Singaraja Bali: Universitas Pendidikan Ganesha Press.

Kustawan, Dedy. (2013). Bimbingan dan Konseling Bagi Anak Berkebutuhan Khusus. Jakarta: Luxima Metro Media.

Rusman. (2012). Model - model Pembelajaran Mengembangkan Profesionalisme Guru. Jakarta: PT. Raja Grafindo Persada.

Soetjiningsih. (2005). Tumbuh Kembang Anak. Jakarta: Penerbit EGC.

Somantri, Sutjihati. (2006). Psikologi Anak Luar Biasa. Bandung: Refika Aditama.

Suciptawati, Ni Luh Putu. (2009). Metode Statistika Non Parametrik Denpasar: Udayana University Press.

Sularyo. (2000). Retardasi Mental. Jurnal Sari Pediatri. Vol 2 No 3. ISSN 23385030.

Sunardi, Sunaryo. (2007). Intervensi Dini Anak Berkebutuhan Khusus. Jakarta: Departemen Pendidikan Nasional.

Sunarto. (2008). Motivasi Belajar. Diakses pada 3 Maret 2020, dari https://sunartombs.wordpress.com/200 8/09/23/motivasi-belajar/ 